\title{
Minicurso de cultura de células animais para alunos de graduação: relato de experiência
}

\author{
Short course of animal cells culture for \\ undergraduate students: experience report
}

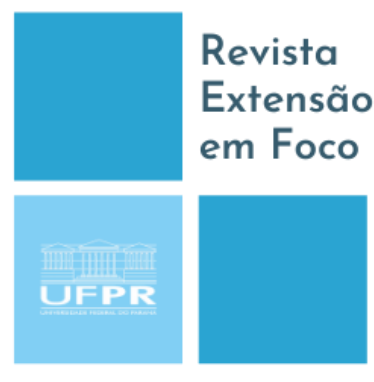

ISSN 2358.7180

\section{Luiz Otávio Lourenço ${ }^{1}$, Ana de Souza Santos² ${ }^{2}$ Cibele Marli Cação Paiva Gouvêa ${ }^{3}$}

\section{RESUMO}

O presente trabalho relata a experiência de um minicurso de cultura de células para alunos de graduação, como atividade complementar. Para a execução do minicurso foi produzido um guia de estudos utilizado para discussão teórica e realização de prática com células animais em cultura. $\mathrm{O}$ impacto da experiência pedagógica nas concepções dos participantes a respeito da cultura celular in vitro foi investigado. Para tanto, os participantes responderam questionário antes do início e ao final do minicurso. Para a verificação da eficiência do minicurso como estratégia de ensino foram realizados três testes: ganho de conhecimento, discriminação e desempenho. A comparação do desempenho dos participantes antes e após o minicurso mostrou que a porcentagem de acertos às respostas do questionário aumentou após o minicurso. Ainda, houve ganho de conhecimento com a atividade realizada e este foi homogêneo. Assim, o minicurso mostrou-se como estratégia eficaz para compor as atividades complementares, contribuindo para a disseminação do conhecimento de temas que não constam na dinâmica curricular.

Palavras-chave: Biologia Celular; Material didático; Metodologia de ensino.

\section{ABSTRACT}

The present work reports the experience of a cell culture short course for undergraduate students, as a complementary activity. For the execution of the short course, a study guide was produced which was used for theoretical discussion and practice with animal cells in culture. The impact of pedagogical experience in participants' conceptions about the in vitro cell culture was investigated. Therefore, the participants answered a questionnaire before the beginning and after of the lecture. For the verification of the efficiency of the lecture as a teaching strategy three tests were carried out: knowledge gain, discrimination and performance. The comparison of participants' performance before and after the lecture showed that the percentage of hits to the answers of the questionnaire increased after the lecture. Still, there was a gain of knowledge with the activity performed and this was homogenous. Hence, short course proved to be an effective strategy to compose the complementary activities, contributing to the dissemination of knowledge of subjects not included in the curriculum.

Keywords: Cell Biology; Teaching materials; Teaching methodology.

\footnotetext{
${ }^{1}$ Graduado. Universidade Federal de Alfenas (UNIFAL-MG), Instituto de Ciências da Natureza, Alfenas, Brasil, luiz_otavio_lourenco@outlook.com. Orcid: https://orcid.org/0000-0002-4801-0406

${ }^{2}$ Graduada. Universidade Federal de Alfenas (UNIFAL-MG), Instituto de Ciências da Natureza, Alfenas, Brasil, ana-souzasantos@ hotmail.com

${ }^{3}$ Doutora em Biologia. Universidade Federal de Alfenas (UNIFAL-MG), Instituto de Ciências da Natureza, Alfenas, Brasil, cibelegouvea@ hotmail.com. Orcid: https://orcid.org/0000-0003-1235-4079
} 


\section{INTRODUÇÃO}

O ensino superior é um sistema complexo que envolve não só a formação profissional, mas também a formação pessoal dos alunos, por meio de ações centradas na dinâmica curricular (CAVALCANTE, 2000).

Assim, no cenário atual de constantes mudanças no perfil dos alunos do ensino superior, os quais apresentam diferentes condições sociais, formação básica e interesses, resultantes das transformações econômicas, sociais e tecnológicas e pela presença de diversos mecanismos de inclusão, as atividades complementares assumem papel importante para garantir a formação sólida de qualidade e o sucesso profissional dos que concluem o ensino superior. As atividades complementares, que compõem os currículos dos cursos de graduação, são diversas e escolhidas pelos próprios alunos, conforme os seus interesses e aptidões, o que proporciona autonomia e responsabilidade pelo desenvolvimento da própria aprendizagem (OLIVEIRA; SANTOS; DIAS, 2016; SANTIAGO; CARVALHO, 2018; SÔNEGO, 2015).

Nesse sentido o presente trabalho utilizou o minicurso como atividade complementar visando disseminar o conhecimento sobre o cultivo de células animais e suas aplicações. Apesar da importância da técnica e de seu uso multidisciplinar, consta em poucos currículos de cursos de graduação, assim, é importante a utilização de metodologias que visem à disseminação e ampliação dos conhecimentos nesta área. $\mathrm{O}$ minicurso é uma estratégia de ensino, cujo objetivo é expor estruturas básicas e técnicas que atendam a diferentes temáticas, a fim de contribuir na formação acadêmica e propagar o conhecimento fora da sala de aula (BERRIEL et al., 2011).

O cultivo de células animais iniciou-se com Harrison e Carrel, no princípio do século XX, para estudar o comportamento destas fora do organismo de origem, em meio controlado. Trata-se de importante ferramenta de pesquisa em laboratórios do mundo todo, sendo as culturas primárias ou as linhagens celulares utilizadas tanto na pesquisa básica como na aplicada, em diferentes áreas da biologia, medicina humana e veterinária, biotecnologia, farmácia e na substituição do uso de animais em testes de laboratório (ALLAMKI; BRADLEY; POBER, 2017; BARBOSA et al., 2015; FRESHNEY, 2010; MERTEN, 2015; MUKHOPADHYAY, 2016). 
Os sistemas de culturas celulares são ferramentas essenciais para ampla gama de estudos biomédicos e clínicos. As células em monocamada são utilizadas para: a obtenção de informação sobre as reações bioquímicas e vias de sinalização em células normais e tumorais, o que permite o estudo de mecanismos moleculares e de resposta ao tratamento; ensaios de citotoxicidade; estudos de penetração e acúmulo de substâncias, fármacos e medicamentos, sendo de extrema importância para a produção e testes de vacinas virais e recombinantes; seleção de novos compostos com propriedades biofarmacêuticas, como os candidatos a medicamentos; produção de medicamentos; reprodução humana e de outros animais; substituição do uso de animais em teste laboratoriais, além de outros. As células com crescimento tridimensional servem como modelos teciduais e têm sido utilizadas em estudos para o desenvolvimento de tecidos e órgãos com uso potencial para transplantes (engenharia tecidual) e como modelos de órgãos e tumores, para estudos bioquímicos e moleculares in vitro, além de outros. Esses modelos reduzem o custo do desenvolvimento de fármacos e medicamentos, possibilitam a triagem mais eficiente de substâncias com potencial medicamentoso, minimizam as taxas de falha e do uso de animais no desenvolvimento e testes de medicamentos e vacinas (AL-LAMKI; BRADLEY; POBER, 2017; BARBOSA et al., 2015; FRESHNEY, 2010; MERTEN, 2015; MUKHOPADHYAY, 2016; AMELIAN et al., 2017; AMARAL; MACHADOSANTELLI, 2011).

O presente trabalho teve como objetivo produzir material didático, ministrar o minicurso sobre o cultivo de células animais para graduandos da Universidade Federal de Alfenas e avaliar a contribuição do minicurso para os participantes.

\section{METODOLOGIA}

\section{Local de desenvolvimento do trabalho}

O trabalho foi desenvolvido no laboratório multidisciplinar do Instituto de Ciências da Natureza, onde são desenvolvidas atividades práticas de culturas de células animais, no campus Sede da Universidade Federal de Alfenas, situado na cidade de Alfenas, no sul do estado de Minas Gerais.

\section{Produção do material didático}


Foi elaborada apostila, que foi disponibilizada no site do grupo do Programa de Educação Tutorial, PET-Biologia da Universidade Federal de Alfenas para download pelos participantes do minicurso, antes da realização deste. A apostila incluiu uma breve introdução sobre o cultivo de células in vitro; biossegurança e assepsia; meios de cultivo; laboratório e equipamentos; tipos de cultura; tipos de células; manutenção e subcultivo; preservação celular; descarte de material; atividade prática e referência bibliográfica (APÊNDICE A).

\section{Minicurso}

O minicurso foi destinado para alunos dos diversos cursos de graduação do campus sede e foram disponibilizadas 80 vagas. $\mathrm{O}$ minicurso constou de parte teórica e parte prática. Na parte teórica foram abordados aspectos básicos sobre o cultivo de células animais. A parte prática constou da apresentação do laboratório de cultura de células e equipamentos e de atividade prática envolvendo: a observação e caracterização morfológica de linhagem de tumor mamário, MCF-7 e de melanoma, MDA-MB-435 aderentes no frasco de cultura, ao microscópio invertido de campo claro e contraste de fase; tripsinização das células; determinação da viabilidade celular pelo método de exclusão de corante, utilizando-se azul de Trypan e observação de lâminas permanentes de células aderentes e não aderentes, provenientes de culturas primárias de ratos Wistar obtidas em aulas práticas (protocolo CEUA 79/2017) e das linhagens MCF-7, MDA-MB435 e K562, ao microscópio ótico comum de campo claro.

\section{Avaliação}

Antes e após a realização do minicurso foram aplicados questionários aos participantes, sem a identificação pessoal, para avaliar o conhecimento prévio e após o minicurso sobre cultura de células animais. Os questionários foram compostos por cinco questões e cada questão teve valor de 0-2. Dessa forma foram avaliados os aspectos similares em cada questionário, com intuito de observar a compreensão dos alunos sobre os temas abordados no minicurso (APÊNCICE B).

A avaliação aplicada antes do minicurso apresentou, questões estruturadas, que foram avaliadas diretamente, atribuindo-se valor 0 ou 2, conforme a resposta estivesse 
errada ou correta, respectivamente. A avaliação aplicada após o minicurso apresentou questões não estruturadas, que foram avaliadas como proposto por Fontoura (2011), sendo atribuídas notas 0 para a resposta completamente errada, 1 para parcialmente correta e 2 para completamente correta.

Para a verificação da eficiência do minicurso como estratégia de ensino foram comparadas as porcentagens das respostas dadas antes e após o minicurso e foram realizados três testes: ganho de conhecimento (g); discriminação (D) e desempenho.

O ganho de conhecimento foi calculado segundo a equação, modificada de Hake (1998):

$\mathrm{g}(\%)=100 \times \underline{(\% \text { alunos com nota } \geq 7,0 \text { final }-\% \text { alunos com nota }}$ $\geq 7,0$ inicial)

(100 - \% alunos com nota $\geq 7,0$ inicial)

0 item discriminação (D) visou distinguir os alunos com bom desempenho daqueles com mal. Os estudantes foram divididos em 2 grupos: com nota $\geq 7,0$ e com nota $<7,0$. 0 valor $D$ fornece informação comparativa sobre o desempenho dos estudantes antes e após a intervenção e foi calculado utilizando-se a fórmula modificada de Shi et al. (2010):

$$
\mathrm{D}=\underline{\text { número de notas } \geq 7,0 \text { - número de notas }<7,0}
$$

número total de alunos/2

O desempenho da turma foi obtido pela comparação entre as médias das notas obtidas nas avaliações realizadas antes e após o minicurso e foi avaliado se a intervenção proporcionou alteração da média.

\section{Análise estatística}

Os dados foram comparados teste $t$ de Student pareado, considerando-se $\mathrm{p}<0,05$, utilizando-se o software GraphPad InStat. 


\section{RESULTADOS E DISCUSSÃO}

A reflexão sobre o sistema educacional superior aponta para a necessidade de reformulação e/ou adequação de currículos para acompanhar as transformações na sociedade, sobretudo nas metodologias de ensino, métodos de avaliação e análise das relações interpessoais no âmbito escolar (GOUVÊA, 2015). É notável a contribuição das aulas práticas para a compreensão do tema em estudo, pois o aluno não se limita a apenas decorar o conteúdo, mas passa a exercitar habilidades e por meio delas, a construir novos conteúdos (KRASILCHIK, 2004). Assim, o minicurso realizado despendeu um quarto do tempo com a parte teórica e três quartos com a parte prática.

O trabalho desenvolvido com os alunos de vários cursos de graduação demonstrou grande interesse e participação dos alunos.

Os resultados obtidos por meio da análise dos questionários demonstraram a compreensão dos alunos sobre o assunto abordado. A comparação da porcentagem de acertos às respostas do questionário aplicado após o minicurso foi, significativamente $(\mathrm{p}=0,04)$, maior do que a porcentagem de acertos obtida antes do minicurso, especialmente, nas questões 2 e 4, talvez por se tratarem de aspectos desconhecidos anteriormente e que após o minicurso foram assimilados (TABELA 1).

Tabela 1 - Porcentagem de acerto para cada questão das avaliações realizadas antes e após o minicurso.

\begin{tabular}{ccc}
\hline Questão & \multicolumn{2}{c}{ Acertos (\%) } \\
\cline { 2 - 3 } & Antes & Após \\
\hline 1 & 85,7 & 88,9 \\
\hline 2 & 28,6 & 100 \\
\hline 3 & 61,9 & 88,9 \\
\hline 4 & 47,6 & 100 \\
\hline 5 & 71,4 & 88,9 \\
\hline \multicolumn{2}{l}{ Fonte: Dados dos pesquisadores (2020). }
\end{tabular}

A análise do ganho de conhecimento $(\mathrm{g})$ demonstrou que o índice $\mathrm{g}$ foi positivo (100\%), portanto, houve ganho de conhecimento com a atividade realizada (TABELA 2). 
Cabe ressaltar que todos os participantes obtiveram nota maior que 7,0 na avaliação após o minicurso. Shi et al. (2010) sugerem que a avaliação do ganho de conhecimento seja feita avaliando-se as respostas dadas em provas, pois a qualidade das respostas é afetada pelo tempo gasto para responder e pela motivação dos alunos. Entretanto, no presente trabalho, mesmo tendo sido realizada avaliação sem caráter de prova, os alunos se empenharam para responder os questionários.

Os resultados deste trabalho apontam que a utilização de minicurso pode contribuir para o processo de ensino e aprendizagem, apresentando-se como uma ferramenta apropriada para a obtenção de aprendizagem significativa, já que houve ganho de conhecimento. A assimilação de conhecimentos ocorre sempre que uma nova informação interage com outra existente na estrutura cognitiva, sendo que o processo contínuo de aprendizagem significativa acontece apenas com a integração de conceitos relevantes, por meio de relação não arbitrária e substantiva (AUSUBEL; NOVAK; HANESIAN, 1980).

Os resultados da discriminação corroboram os dados para o ganho de conhecimento observado no presente estudo, pois houve aumento do índice D obtido após (2), quando comparado ao índice obtido antes $(0,28)$ do minicurso (TABELA 2). Assim, o aumento do índice g, indica ganho de conhecimento e pode-se afirmar que o ganho de conhecimento foi homogêneo, pois houve aumento do índice D. Este resultado é interessante, pois sugere que o minicurso possa ser uma estratégia para atingir grande parte de alunos, contribuindo, positivamente, para o processo de ensino e aprendizagem.

A avaliação do desempenho, obtida pela média das notas nas avaliações aplicadas antes e após a realização do minicurso, permitiu observar que a média final $(8,7)$ foi significativamente $(\mathrm{p}=0,0001)$ maior que a inicial $(6,3)$, o que demonstra conhecimento homogêneo, mesmo se tratando de alunos participantes provenientes de diferentes cursos de graduação (TABELA 2). Este dado sugere que o minicurso possa ser uma boa estratégia a ser utilizada na prática docente.

Tabela 2. Resultados dos testes de ganho de conhecimento, discriminação e desempenho.

\begin{tabular}{ccccc}
\hline $\begin{array}{c}\text { Ganho de } \\
\text { conhecimento }(\mathbf{g}) *\end{array}$ & \multicolumn{2}{c}{ Discriminação $(\mathbf{D})^{* *}$} & \multicolumn{2}{c}{ Desempenho*** $^{* *}$} \\
\cline { 2 - 5 } & Antes & Após & Antes & Após \\
\hline $100 \%$ & 0,28 & 2 & 6,3 & 8,7 \\
\hline
\end{tabular}


*g positivo indica ganho de conhecimento; ** aumento de D indica conhecimento homogêneo; *** média das notas obtidas nas avaliações aplicadas antes e após a realização do minicurso. Fonte: Dados dos pesquisadores (2020).

Os resultados deste trabalho demonstram que o minicurso contribuiu para o ganho de conhecimento sobre os princípios da cultura de células. O material didático produzido foi importante para que os participantes acompanhassem a parte teórica do minicurso e foi fundamental para a correta execução dos procedimentos experimentais desenvolvidos neste trabalho. Assim, este trabalho aponta que por meio de atividades complementares, o aprendizado pode ser obtido sob o viés científico de transmissão de conhecimento.

\section{CONCLUSÕES}

Os resultados deste trabalho demonstraram que o minicurso possibilitou o conhecimento sobre cultura de células animais e suas aplicações. Houve interesse e participação dos alunos, bem como melhora do desempenho da turma após o minicurso, também houve ganho de conhecimento e este foi homogêneo, indicando a eficácia do minicurso como estratégia didática, especialmente, para compor as atividades complementares oferecidas pela instituição de ensino superior.

\section{AGRADECIMENTOS}

Ao PET-MEC-SESu pela concessão de bolsa aos autores.

\section{REFERÊNCIAS}

AL-LAMKI, R.; BRADLEY, J.; POBER, J. Human organ culture: updating the approach to bridge the gap from in vitro to in vivo in inflammation, cancer, and stem cell biology. Frontiers in Medicine, Lausanne, v. 4, p. 148, 2017.

AMARAL, J. B.; MACHADO-SANTELLI, G. M. A cultura de células em 3 dimensões e a sua aplicação em estudos relacionados a formação do lúmen. Naturalia, Rio Claro, v. 34, p. 1-20, 2011. 
AMELIAN, A. et al. Application of standard cell cultures and 3D in vitro tissue models as an effective tool in drug design and development. Pharmacological Reports, Kracóvia, v. 69, n. 5, p. 861-870, 2017.

AUSUBEL, D.; NOVAK, J.; HANESIAN, H. Psicologia educacional. 2. ed. Rio de Janeiro: Interamericana, 1980.

BARBOSA, B. S. et al. Histórico do desenvolvimento do cultivo de células animais. Uma revisão. Revista Brasileira de Higiene e Sanidade Animal, Fortaleza, v. 9, n. 2, p. 334-347, 2015.

BERRIEL, Y. G. et al. Mini-curso Biologia Forense: A ciência desvendando o crime - discutindo tecnologia e ciência em sala de aula. Colloquium Humanarum, Presidente Prudente, v. 8, n. 1, p. 53-58, 2011.

CAVALCANTE, J. F. Educação superior: conceitos, definições e classificações. Brasília: Instituto Nacional de Estudos e Pesquisas Educacionais, 2000.

FONTOURA, H. A. Tematização como proposta de análise de dados na pesquisa qualitativa. In: FONTOURA, H. A.l (Org.). Formação de professores e diversidades culturais: múltiplos olhares em pesquisa. Niterói: Intertexto, 2011.

FRESHNEY, R. I. Culture of animal cells: a manual of basic technique and specialized applications. 6. ed. New York: John Wiley and Sons, 2010.

GOUVÊA, C. M. C. P. Seminários: proposta didática para o ensino de Genética. Revista de Ensino de Bioquímica, São Paulo, v. 13, n. 3, p. 22-35, 2015.

HAKE, R. Interactive-engagement versus traditional methods: a six-thousandstudent survey of mechanics test data for introductory physics courses. American Journal of Physics, Washington, v. 66, n. 1, p. 64-74, 1998.

KRASILCHIK, M. Prática de ensino de Biologia. 4. ed. São Paulo: Editora da Universidade de São Paulo, 2004.

MERTEN, O.-W. Advances in cell culture: anchorage dependence. Philosophical Transactions of the Royal Society of London, Series B, Biological Science, Londres, v. 370, n. 1661, p. 20140040, 2015. 
MUKHOPADHYAY, A. Mammalian cell technology and its applications. 2. ed. Deli: I K International Publishing House, 2016.

OLIVEIRA, C. T.; SANTOS, A. S.; DIAS, A. C. G. Percepções de estudantes universitários sobre a realização de atividades extracurriculares na graduação. Psicologia: Ciência e Profissão, Brasília, v. 36, n. 4, p. 864-876, 2016.

SANTIAGO, S. A.; CARVALHO, H. F. Estratégia de ensino: Aprenda em sala de aula. Revista de Ensino de Bioquímica, São Paulo, v. 16, n. 1, p. 51-73, 2018.

SHI, J. et al. A diagnostic assessment for introductory Molecular and Cell Biology. CBE Life Science Education, Bethesda, v. 9, n. 4, p. 453-461, 2010.

SÔNEGO, A. Os desafios da universidade no século XXI e algumas reflexões sobre a posição docente frente a este processo. Revista Brasileira de Ensino Superior, Passo Fundo, v. 1, n. 1, p. 30-35, 2015.

\title{
APÊNCICE A
}

\section{MATERIAL DIDÁTICO PRODUZIDO}

\author{
Cultivo de células animais \\ Animal cells culture
}

\section{INTRODUÇÃO}

O cultivo celular consiste em um conjunto de técnicas que permite a sobrevivência e proliferação das células fora do organismo de origem em condições controladas, ou seja, in vitro. $\mathrm{O}$ cultivo de células animais iniciou-se com Harrison e Carrel, no princípio do século XX, para estudar o comportamento destas fora do organismo de origem, em meio ambiente controlado.

Hoje é amplamente disseminado e tornou-se importante ferramenta de pesquisa em laboratórios do mundo todo, sendo as culturas primárias ou as linhagens celulares utilizadas tanto na pesquisa básica como na aplicada, em diferentes áreas da biologia, medicina humana e veterinária, biotecnologia, farmácia e na substituição do uso de animais em testes de laboratório. Isso ocorre devido à diversidade de modelos e origens celulares, ao relativo fácil manuseio, até mesmo para a inserção e deleção de genes e por não se tratar de técnica onerosa.

As células em cultura são mantidas em ambiente artificial, em condições ótimas de temperatura, nutrientes, umidade e na ausência de contaminantes. Assim, as células são mantidas em condições estéreis, semelhantes às do organismo de origem, porém, fora dele, em frasco de cultura (in vitro), contendo meio líquido para cultivo celular. Para 
tanto, são manipuladas em ambiente estéril, no interior da câmara de fluxo laminar. $\mathrm{O}$ meio de cultura propicia condições semelhantes às in vivo, fornecendo nutrientes essenciais e ainda regula o $\mathrm{pH}$ e a osmolaridade, o que permite a sobrevivência e proliferação celular. As células também necessitam de temperatura controlada, sendo mantidas, geralmente, a $37^{\circ} \mathrm{C}$, em incubadora com atmosfera umidificada contendo $5 \%$ de $\mathrm{CO}_{2}$. As culturas celulares requerem sua manutenção, caracterizada pela substituição do meio de cultivo celular e o subcultivo.

\section{BIOSSEGURANÇA E ASSEPSIA}

Células são unidades muito pequenas e, portanto, exigem cuidado no manuseio, com isso a proteção contra contaminação e o manejo delicado são fundamentais para a condução dos trabalhos com células.

\section{Biossegurança}

O trabalho com células em cultura deve ser conduzido nas condições mais seguras possíveis, por isso é preciso planejar o trabalho antes do seu início. É obrigatório o uso de jaleco/avental, luvas de látex, touca, máscara cirúrgica, propé assim como o uso de calça comprida e sapatos fechados para evitar a contaminação e riscos à saúde. O uso de anéis, relógios e pulseiras deve ser restrito. Antes de iniciar o trabalho com as células devem-se lavar as mãos e a parte anterior do antebraço com água e sabão, realizar antissepsia das mãos com álcool $70 \%$ (v/v) e calçar luvas cirúrgicas. Todo trabalho com células que não estejam contaminadas com patógenos, deve ser conduzido em cabine de fluxo laminar com segurança de Classe II. Antes de deixar o laboratório, devem-se lavar as mãos cuidadosamente.

A entrada no laboratório de cultura de células deve ser restrita ao pessoal treinado para a condução do trabalho com células. $\mathrm{O}$ número de pessoas deve ser limitado à capacidade do laboratório para minimizar riscos.

\section{Assepsia}

A limpeza dos equipamentos deve ser feita periodicamente para controle microbiológico. As células são mantidas em condições assépticas, assim todo material ou substância que entra em contato com as células deve ser estéril e a manipulação é feita em cabine de fluxo laminar. Os materiais e soluções podem ser esterilizados por calor úmido (autoclave), filtração ou radiação. A radiação ultravioleta (UV) é utilizada para a assepsia da superfície dos materiais e da cabine de fluxo laminar, antes da manipulação das células. O álcool 70\% (v/v) é utilizado para a assepsia da superfície dos materiais, bancadas e da incubadora.

\section{LABORATÓRIO E EQUIPAMENTOS}

\section{Laboratório}

A organização de um laboratório para o trabalho com culturas celulares depende da sua finalidade e do número de pessoas que nele trabalharão. De maneira geral, o 
laboratório necessita das seguintes áreas: estéril, de suporte e experimentação. A área estéril é destinada à manipulação e incubação das células. A área de manipulação deve ser adjacente à de incubação, longe da entrada e passagem de pessoal. A área de suporte destina-se à lavagem, preparo de material e esterilização. A área de experimentação destina-se à contagem, caracterização e análise das células em cultura.

\section{Equipamentos}

O laboratório de cultura de células deve ter um conjunto de equipamentos básicos para as técnicas de cultivo, além de outros específicos para a finalidade do trabalho com as células. Para o funcionamento do laboratório de cultura de células os seguintes equipamentos são fundamentais: cabine de fluxo laminar, estufa incubadora de $\mathrm{CO}_{2}$, autoclave, microscópio invertido de campo claro e contraste de fase, microscópio binocular de campo claro, ultrafreezer, container de nitrogênio líquido, freezer, geladeira, estufa para secagem de material, centrífuga, banho-maria, balança analítica, destilador de água, medidor de $\mathrm{pH}$, agitador magnético e bomba de vácuo.

\section{TIPOS DE CULTURAS}

As culturas celulares são classificadas em: primária, linhagem finita e linhagem contínua. As linhagens podem ser estabelecidas ou adquiridas em banco de células como o Banco de Células do Rio de Janeiro, Americam Type Culture Collection Cell Lines, The European Collection of Authenticated Cell Cultures, além de outros.

\section{Cultura primária}

Cultura estabelecida com as células obtidas diretamente do tecido animal ou humano, normal ou tumoral, até que seja subcultivada. Um fragmento de tecido, o explante, é obtido do organismo doador das células. No caso de tecido sanguíneo ou medula óssea, as células não necessitam de dissociação para o cultivo e podem ser transferidas diretamente para o frasco contendo meio de cultura. No caso de tecidos sólidos, para o estabelecimento da cultura é necessária à dissociação celular. Assim, o explante deve ser finamente fragmentado com auxílio de instrumento cortante ou seringa (desagregação mecânica) ou as células podem ser dissociadas por ação enzimática. Após a dissociação celular, estas são transferidas para o frasco contendo meio de cultura e incubadas na estufa de $\mathrm{CO}_{2}$. A cultura primária é um recurso vantajoso por manter as características do tecido de origem, porém, pode ser mantida por período de tempo limitado.

\section{Linhagem finita}

Obtida do subcultivo de culturas primárias, que não sofreram transformação e tem capacidade de proliferação por tempo limitado, quando entram em senescência e morte.

\section{Linhagem contínua}


Cultura de um único tipo celular, com capacidade ilimitada de proliferação, devido à ocorrência de mutações espontâneas ou induzidas, que tornam as células imortalizadas e permitem sua existência por muitos anos. Tendo em vista que as células podem se dividir indefinidamente, estas podem ser propagadas e expandidas para formarem bancos celulares. Este tipo de cultura é muito utilizado em pesquisas e para obtenção de produtos farmacêuticos como vacinas, hormônios e anticorpos, além de serem utilizadas para a proliferação de vírus de interesse para a saúde humana e animal.

\section{TIPOS DE CÉLULAS}

As células como ocorrem no organismo, realizam interações entre si e com a matriz extracelular e essas interações estão relacionadas à sua disposição na cultura, podendo ser células aderentes ou não aderentes e de acordo com a morfologia são classificadas em epiteliais, fibroblásticas e linfoblásticas, sendo as últimas não aderentes.

\section{Células aderentes}

As células aderentes são, geralmente, oriundas de órgãos sólidos e precisam de ancoragem para se propagar e, em geral, o suporte é fornecido pelo frasco de cultura ou pode-se utilizar um arcabouço (scaffold). No primeiro caso crescem em monocamada (2D) e no segundo são capazes de formar estrutura tridimensional (3D).

\section{Células não aderentes}

Crescem em suspensão no meio, sem necessidade de ancoragem. São oriundas da linhagem sanguínea normal ou tumoral e de células adaptadas ao crescimento em suspensão.

\section{Células mistas}

Em alguns casos as células se comportam como população mista, crescendo de forma aderente e em suspensão.

\section{CULTIVO E SUBCULTIVO}

\section{Cultivo}

As células são cultivadas em frascos de cultura contendo meio de cultura líquido, que fornece os nutrientes e é responsável pela manutenção do $\mathrm{pH}$ e osmolaridade, simulando as condições fisiológicas de um organismo. Existem diferentes frascos para a cultura celular, bem como diferentes meios de cultura, com diferentes composições, que proporcionam as condições nutritivas para a sobrevivência e proliferação celular, sendo a escolha do meio direcionada pelo tipo de célula a ser cultivada. Os tipos de meios de cultura são: quimicamente definido, livre de compostos de origem animal e meio livre de soro. Os mais amplamente utilizados são os meios quimicamente definidos, que requerem a adição de soro, o qual fornece hormônios, fatores de crescimento, proteínas diversas, como as de adesão celular, além de outros componentes, que regularam a permeabilidade 
da membrana plasmática e o carreamento de substâncias para o interior da célula. O soro fetal bovino é um dos mais utilizados por possuir menor quantidade de imunoglobulinas e elevada proporção de fatores de crescimento, favorecendo a manutenção das condições ideais ao cultivo de ampla gama de células animais e humanas.

Os meios de cultura estão disponíveis na forma líquida, pronta para uso ou em pó, que deve ser preparado, segundo as instruções do fabricante e esterilizado antes do uso.

Para a prevenção de contaminação bacteriana utilizam-se antibióticos de amplo espectro, que são adicionados ao meio de cultivo. Os mais comumente utilizados são penicilina $(100 \mathrm{U} / \mathrm{mL})$ e estreptomicina $(100 \mu \mathrm{g} / \mathrm{mL})$ ou gentamicina $(50 \mu \mathrm{g} / \mathrm{mL})$. Os antifúngicos devem ter uso bem limitado, tendo em vista que são muito tóxicos para as células em cultura. O mais utilizado é a anfotericina B $(2,5 \mu \mathrm{g} / \mathrm{mL})$. O uso de antibióticos não é recomendado para as culturas celulares que se destinam à produção de biofármacos e vacinas virais.

\section{Subcultivo}

As células em cultura utilizam os nutrientes do meio de cultura para as suas reações metabólicas, as quais produzem substâncias tóxicas e estas substâncias são exportadas da célula para o meio de cultura, como ocorre com o lactato. Assim, para que as células se mantenham vivas e metabolicamente ativas no frasco de cultura, o meio de cultura deve ser substituído, em geral a cada dois dias. À medida que as células se proliferam no frasco de cultura, além de consumirem os nutrientes do meio também ocorre aumento da população celular; o número excessivo de células pode inibir seu crescimento e levar as células à morte. Assim, é essencial o subcultivo, ou seja, a remoção periódica das células de um frasco de cultura e a distribuição dessas células em outros frascos (subcultivo).

O subcultivo das células não aderentes deve ser feito transferindo-se parte das células do frasco de cultura para outro e deve-se completar o volume dos frascos com meio novo. A cada 15 dias todo o meio deve ser substituído, utilizando-se centrifugação e diluição do precipitado celular em novo meio.

Para o subcultivo das células aderentes é necessário que estas sejam destacadas do frasco de cultura. Esta ação é exercida pela tripsina, uma enzima proteolítica, que promove a desagregação das células pela lise de proteínas da matriz extracelular. É preciso controlar o tempo de ação da tripsina, para que atue apenas sobre as proteínas extracelulares, uma vez que se trata de enzima proteolítica de amplo espectro. Assim, se permanecer muito tempo em contato com as células, ocorrerá a lise das proteínas da membrana citoplasmática, inviabilizando as células. A tripsina pode ser inativada pelo soro fetal bovino, pois este contém o fator $\langle-1$ antitripsina, uma glicoproteína da família dos inibidores de serina-proteases, dentre elas a tripsina. Após a tripsinização as células são centrifugadas, o sobrenadante é descartado, o precipitado celular é ressuspenso em meio de cultura e subdividido em vários frascos de cultura.

\section{PRESERVAÇÃO CELULAR}

A preservação das células dá-se por criopreservação, que consiste no processo de congelamento e armazenamento em nitrogênio líquido à temperatura de $-196^{\circ} \mathrm{C}$. Esse processo protege as células de alterações em seu DNA decorrentes das frequentes divisões 
celulares. Além disso, as células são conservadas por período indeterminado de tempo, permitindo a retomada do desenvolvimento celular normal após o descongelamento. $\mathrm{O}$ processo de congelamento mais usado é o congelamento lento. Esse processo caracterizase pela redução gradual de temperatura, que permite a desidratação celular gradual, reduzindo a formação de cristais de gelo no interior da célula.

Para o congelamento celular é necessário o uso de crioprotetores, que possuem a capacidade de proteger a membrana citoplasmática dos danos do congelamento e da desidratação. O crioprotetor mais utilizado é o dimetilsufóxido (DMSO). O glicerol é utilizado para um número limitado de células. De forma geral, os crioprotetores atuam capturando as moléculas de água livre, o que leva à redução da quantidade de gelo formada e diminuição da temperatura do ponto de congelamento. O DMSO penetra em tecidos e células mais rapidamente que o glicerol, sendo mais eficiente para a preservação da viabilidade celular, contudo, ambos são tóxicos. A criopreservação é utilizada tanto para as células aderentes como para as não aderentes e ocorre da mesma forma para ambos os tipos de células.

O descongelamento das células permite a retomada do metabolismo celular e deve ocorrer de forma rápida, a $37^{\circ} \mathrm{C}$, seguido da lavagem das células para a retirada do crioprotetor utilizado.

\section{DESCARTE DE MATERIAL}

As culturas, assim como todos os resíduos da manipulação, devem ser descontaminados antes da lavagem ou descarte. O meio de cultura, resíduos líquidos, os frascos de cultura, ponteiras ou outros materiais descartáveis, bem como pipetas e outros materiais de vidro que entraram em contato com as células devem permanecer em solução de hipoclorito de sódio de 3 a 5\% (v/v) por 2 a 12 horas. Depois disso o resíduo líquido pode ser descartado na pia e os sólidos em lixo contaminado com resíduo biológico (branco). O material de vidro deve ser lavado adequadamente antes de reutilizado.

Culturas contaminadas não devem ser abertas e devem ser descontaminadas, tão logo sejam observadas, em autoclave durante $1 \mathrm{~h}$ a $121^{\circ} \mathrm{C}$, antes do descarte em lixo contaminado com resíduo biológico (branco). Se algum material entrou em contato com as culturas contaminadas, estes também devem ser descontaminados antes do descarte ou lavagem.

\section{ATIVIDADE PRÁTICA}

A atividade prática a ser desenvolvida tem como objetivo fornecer noções sobre o cultivo de células animais, tais como: utilização do microscópio invertido, observação de células no frasco de cultura, tripsinização, contagem de células viáveis, coloração, a análise morfológica, bem como a observação de alguns tipos de células em cultura.

\section{Observação e lavagem dos frascos de cultura com células tumorais aderentes}

-Observar as células ao microscópio invertido;

-Remover o meio de cultura, com auxílio de pipeta; 
-Lavar a garrafa de cultura com $2 \mathrm{~mL}$ de solução salina $0,85 \%(\mathrm{~m} / \mathrm{v})$ por duas vezes (remover a salina com auxílio de uma pipeta).

\section{Tripsinização e observação das células}

A tripsinização tem como objetivo destacar as células que estão aderidas ao frasco de cultura. Assim, a tripsina, enzima proteolítica, degrada as proteínas da matriz extracelular, liberando as células que nela estão aderidas. Contudo, o tempo de contato com a tripsina deve ser limitado para que não haja lise da membrana citoplasmática.

-Adicionar $2 \mathrm{~mL}$ de tripsina 0,25\%, contendo EDTA 0,02\%, na garrafa de cultura lavada com solução salina;

-Incubar por 3 min. e monitorar as células ao microscópio invertido;

-Neutralizar a ação da tripsina com $1 \mathrm{~mL}$ de soro fetal bovino;

-Observar as células, no frasco de cultura, ao microscópio invertido.

\section{Determinação da viabilidade celular com Trypan blue}

A determinação da viabilidade celular com o corante Trypan blue se baseia no método de exclusão de corante. Este corante só atravessa a membrana citoplasmática se esta possuir lesão, acumulando-se no interior da célula. Assim, as células não coradas são viáveis e as células coradas de azul são inviáveis. As células são quantificadas em câmara hemocitométrica de Neubauer, utilizando-se o microscópio ótico comum.

-Após a tripsinização das células, transferir a suspensão celular para um tubo Falcon, com auxílio de pipeta;

-Lavar a garrafa de cultura com $1 \mathrm{~mL}$ de solução salina $0,85 \%(\mathrm{~m} / \mathrm{v})$ e transferir a solução para o tubo Falcon contendo as células;

-Centrifugar a $800 \mathrm{xg}$, por $5 \mathrm{~min}$;

-Remover o sobrenadante com uma pipeta Pasteur, deixando um pequeno volume de sobrenadante;

-Ressuspender as células em $100 \mu \mathrm{L}$ de solução salina;

-Homogeneizar as células, transferir uma alíquota de $25 \mu \mathrm{L}$ de células para um tubo eppendorf contendo $25 \mu \mathrm{L}$ de Trypan blue e acrescentar $200 \mu \mathrm{L}$ de salina;

-Colocar a lamínula sobre a área demarcada na câmara de contagem;

-Homogeneizar bem a suspensão celular, retirar uma alíquota de $10 \mu \mathrm{L}$ e encostando a ponta da pipeta na borda da lamínula, preencher cuidadosamente a câmara de contagem (FIGURA 1A);

-O líquido deve preencher apenas um lado da câmara e não deve chegar aos canais de cada lado da área de contagem;

-Deixar as células se sedimentarem por 2 min; 
-Focalizar a área demarcada da câmara de contagem, ao microscópio ótico comum vertical, com a objetiva de menor aumento e identificar as áreas 1, 2, 3 e 4; o volume de cada área com a lamínula colocada corresponde a 0,1 mL (FIGURA 1B);

-Contar as células nas 4 áreas de um lado da câmara de contagem, seguindo o esquema da Figura 1C;

-As células que tocarem nas linhas superior e esquerda, que limitam o quadrante devem ser contadas e as que tocarem nas linhas direita e inferior não devem ser contadas - 2 linhas permitidas e 2 linhas proibidas (FIGURA 1C);

-Utilizar os seguintes critérios para contagem das células: contar células isoladas (com núcleo bem visível), como 1 célula; contar grumos constituídos por células facilmente distinguíveis por seus núcleos e citoplasmas como células isoladas e contar cada célula; grumos, cujas células sejam difíceis de serem distinguidas umas das outras, devem ser contados como um único grupo (FIGURA 1D);

-Não contar as células coradas de azul (células não viáveis);

-Calcular o número de células viáveis no frasco, utilizando a seguinte fórmula:

Células viáveis $/ \mathrm{mL}=\underline{\text { total de células viáveis contadas } \mathrm{x} \text { fator de diluição x } 10.000}$

\section{4}

Figura 1 - Contagem de células viáveis em câmara de Neubauer. A, preenchendo a câmara; $\mathbf{B}$, quadrantes a serem contados (1, 2, 3 e 4); $\mathbf{C}$, esquema para contagem das células em um quadrante; notar que as células que tocam as linhas superior e esquerda, que limitam o quadrante devem ser contadas e as que tocam as linhas direita e inferior não devem ser contadas; D, células isoladas, grumos de células com núcleos visíveis e grumos com núcleo não visíveis.

A
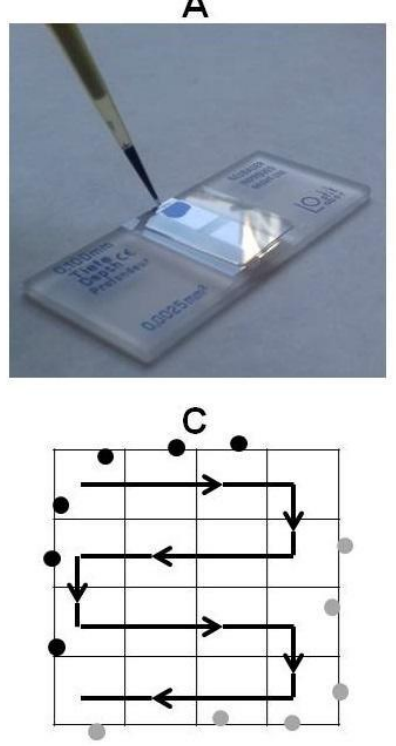

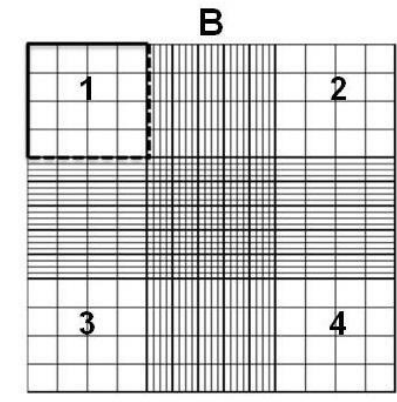

D

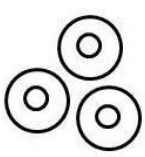

Isoladas

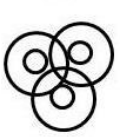

Núcleos

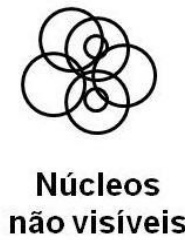

Fonte: Dados dos pesquisadores (2020).

Observação de lâminas de cultura primária de hepatócito de rato, de linhagem aderente e de linhagem não aderente. 
-Observação em microscópio ótico comum;

-Colocar a lâmina na platina e focalizar com as objetivas de aumento de 4x e depois de 10x;

-Proceder a iluminação de Köhler para ajuste da iluminação da amostra, de modo a produzir a melhor qualidade de imagem, com brilho uniforme e sem excessos;

-Com a amostra focalizada com a objetiva de 10x, fechar o diafragma de campo;

-Fechar o diafragma íris do condensador, até que uma imagem geométrica seja observada (bordas do diafragma de campo);

-Focalizar as bordas da imagem geométrica abaixando ou elevando o condensador, até que as bordas fiquem nítidas;

-Abrir o diafragma íris do condensador até a abertura numérica desejada;

-Abrir o diafragma de campo até iluminar todo o campo de visão;

-Colocar na objetiva desejada para a análise, sempre observando a correta abertura do diafragma íris do condensador, de acordo com a abertura numérica necessária para a objetiva;

-Observar as lâminas de células em cultura coradas com hematoxilina-eosina; identificar o núcleo, nucléolos e citoplasma;

-Comparar a morfologia das diferentes células.

\section{REFERÊNCIAS}

ALVES, E. A.; GUIMARÃES, A. C. R. Cultivo celular. In: MOLINARO, E. M.; CAPUTO, L. F. G.; AMENDOEIRA, M. R. R. (Eds.). Conceitos e métodos para a formação de profissionais em laboratórios de saúde: v. 2. Rio de Janeiro: EPSJV, 2010.

FRESHNEY, R. I. Culture of animal cells: a manual of basic technique and specialized applications. 6. ed. New York: John Wiley and Sons, 2010.

MUKHOPADHYAY, A. Mammalian cell technology and its applications. 2. ed. Deli: I K International Publishing House, 2016.

PERES, C. M.; CURI, R. Como cultivar células. Rio de Janeiro: Guanabara Koogan, 2005.

\section{APÊNCICE B}

\section{QUESTIONÁRIOS}

Os Quadros 1 e 2 apresentam os questionários aplicados antes e após a realização do minicurso de cultura de células animais.

Quadro 1 - Questionário 1, aplicado antes do início do minicurso: Cultivo de células animais 


\begin{tabular}{|c|c|}
\hline Questão & Alternativa \\
\hline $\begin{array}{l}\text { 1. Classifique de acordo com as opções } \\
\text { abaixo: } \\
\text { A- Células aderentes; B- Células não } \\
\text { aderentes; C- Células mistas. }\end{array}$ & $\begin{array}{l}\text { ( ) Contém células aderentes e em suspensão. } \\
\text { ( ) Crescem em suspensão no meio sem necessidade } \\
\text { de ancoragem. } \\
\text { ( ) Necessitam de ancoragem para iniciar sua } \\
\text { proliferação. }\end{array}$ \\
\hline $\begin{array}{l}\text { 2. Analise as informações abaixo e } \\
\text { assinale a alternativa que trata dos } \\
\text { requisitos básicos para o cultivo celular } \\
\text { in vitro: }\end{array}$ & $\begin{array}{l}\text { a) A classificação das culturas se relaciona } \\
\text { diretamente com o tempo ao qual foram cultivadas. } \\
\text { b) Os tipos de células são classificados em aderentes, } \\
\text { não aderentes e mistas. } \\
\text { c) O soro fetal bovino é utilizado no cultivo de células, } \\
\text { pois favorece a manutenção de condições ideais ao } \\
\text { cultivo. }\end{array}$ \\
\hline $\begin{array}{l}\text { 3. A linhagem de células tumorais faz } \\
\text { parte de que tipo de linhagem celular? }\end{array}$ & $\begin{array}{l}\text { a) Linhagem apenas aderente } \\
\text { b) Linhagem somente primária } \\
\text { c) Linhagem contínua }\end{array}$ \\
\hline $\begin{array}{l}\text { 4. Para o subcultivo das células } \\
\text { aderentes é necessário que estas sejam } \\
\text { destacadas do frasco de cultura. Esta } \\
\text { ação é exercida pela tripsina. Qual é a } \\
\text { finalidade desta enzima proteolítica? }\end{array}$ & $\begin{array}{l}\text { a) Promover a agregação das células por lise de } \\
\text { proteínas da matriz extracelular. } \\
\text { b) Promover a desagregação das células por lise de } \\
\text { proteínas da matriz extracelular. } \\
\text { c) Promover a desagregação das células por lise de } \\
\text { proteínas intracelulares. } \\
\text { d) Promover a agregação das células por lise de } \\
\text { proteínas intracelulares. }\end{array}$ \\
\hline $\begin{array}{l}\text { 5- Para o congelamento celular é } \\
\text { necessário o uso de crioprotetores. } \\
\text { Quais dos crioprotetores abaixo são os } \\
\text { mais utilizados e apresentam baixa } \\
\text { toxicidade? }\end{array}$ & $\begin{array}{l}\text { a) Etilenoglicol e glicerol } \\
\text { b) Propanodiol e dimetilsulfóxido } \\
\text { c) Glicerol e propanodiol } \\
\text { d) Glicerol e dimetilsulfóxido }\end{array}$ \\
\hline
\end{tabular}

Fonte: Dados dos pesquisadores (2020).

Quadro 2 - Questionário 2, aplicado após a realização do minicurso: Cultivo de células animais

1. Trata-se de o estágio inicial do cultivo, quando as células são recém-tiradas do tecido vivo. Qual o tipo de cultura em questão? Como as células podem ser classificadas de acordo com as interações relacionadas à sua disposição no frasco de cultura?

2. Qual é o soro mais utilizado no cultivo de células, que fornece requisitos ideais ao cultivo?

3. Algumas culturas de células são chamadas "linhagem de células tumorais". Explique o motivo de tal nome e uma aplicação dada a esse tipo de cultura celular.

4. Qual é a enzima proteolítica utilizada para o subcultivo das células aderentes?

5. Para o congelamento celular é necessário o uso de crioprotetores. Quais crioprotetores são os mais utilizados e apresentam baixa toxicidade? Explique como funcionam.

Recebido em: 15 de junho de 2020.

Aceito em: 07 de novembro de 2020. 